\title{
CONSTITUTIONAL SCAPEGOAT: THE DIALECTIC BETWEEN HAPPINESS AND APARTHEID IN SOUTH AFRICA
}

\author{
Saul Tourinho Leal*
}

Key words: South Africa; Apartheid; institutionalised sadism; Africa; right to happiness; human dignity; Constitution

\section{INTRODUCTION}

The consequences of South Africa's apartheid era are still visible in terms of their effects on the South African economy, and in terms of the racism which has eroded various human rights. Apartheid may be seen to be the result of arrogant and racially discriminant economic development by the white minority, which resulted in

* The author was awarded a Vice-Chancellor Postdoctoral Fellowship by the University of Pretoria, to be conducted at the Institute for International and Comparative Law in Africa (ICLA), under the supervision of Professor Charles Fombad. He clerked for Justice Edwin Cameron at the Constitutional Court of South Africa. Living in South Africa since 2014, he was a visiting researcher at the University of Cape Town under the supervision of Professor Pierre de Vos and also at the South African Institute for Advanced Constitutional, Public, Human Rights and International Law (SAIFAC), under the supervision of Professor David Bilchitz. He is the President of the Brazilian Bar Association's Sub-Committee on Foreign Relations with South Africa. It is of paramount importance to thank my colleagues at the Institute for International and Comparative Law in Africa (ICLA), especially Professor Charles Fombad, from whom I received all enthusiasm and incentive. 
inequality and injustice. The implementation of public economic policies, where the end justifies the means, creates the opportunity to use scapegoats in order to justify economic injustices to the public.

In order to demonstrate how the South African apartheid leaders could manipulate justice and equality in order to enforce their own will, this paper addresses the history of the misuse of "right to happiness" during the apartheid era. This paper aims to illustrate how political and legal manipulation are used to turn Constitutional values into scapegoats; as the apartheid regime used happiness as the perfect scapegoat to justify white supremacy. This conduct is also evident in other African countries where their Constitutions repudiate economic exploitation under the mantle of the right to happiness.

This demonstration shows that, by denying rights, obstructing democratic channels, neglecting the assumed commitment to socio-economic rights, and corrupting the sense of human dignity, authoritarian political regimes do nothing in favour of the people's happiness, in spite of their hypocritical claims to the contrary.

\section{HAPPINESS AS SCAPEGOAT: APARTHEID AND ITS MOTIVATIONS}

Some political speeches announce tragedies. In South Africa, the tragedy was announced during a radio broadcast on 17 March 1961, when the people heard the following statement: "The policy of separate development is designed for happiness, security, and stability (...) for the Bantu as well as the whites." It was the first phrase proclaimed by the Prime Minister of the Union of South Africa, Hendrik Verwoerd, in the introduction of his Address to the Nation. The policy of separate development would prove to be a scandalous euphemism. Verwoerd continued to promise that "we shall provide all our races with happiness and prosperity". ${ }^{2}$ Verwoerd would become known as "the architect of apartheid".

The South African Governor-General was Supreme Chief in the Transvaal up until 1956. At that time, Cape Africans were considered too advanced to be treated as an underclass. Elizabeth Landis, an American expert on Southern Africa affairs, explains that the government had to change this consideration, with the explanation that "if we want to bring peace and happiness to the Native population (...) then we

1 In the eighteenth century, the Enlightenment philosophy gained importance in the United States, led by Jeremy Bentham. According to him all laws should produce as much happiness as possible so that citizens and society as a whole could be happy. In any public or private decision consideration was required to be given to how it would result in the happiness of all people concerned, each and every one being regarded as equal. This is the "Greatest Happiness Principle". Bentham, James Mill and John Stuart Mill became utilitarians. They conducted studies geared towards measuring quantitative hedonism's capacity to address ethical issues by quantifying pleasure to be generated through the implementation of one or another policy.

2 Verwoerd 1961. 
cannot do otherwise than to apply this principle, which has worked so effectively in the other three provinces, to the Native population of the Cape as well (...)".3 Happiness therefore becomes a scapegoat.

The unprecedented consequences of apartheid followed swiftly. As Otto Friedrich remembers:

By 1965, apartheid had become so obsessively established that a white taxi driver refused to let a blind white girl and her colored nurse ride together in his cab; that white and colored children were forbidden to appear together in a Red Cross pageant. ${ }^{4}$

The appalling events did not cease. Friedrich explains that "Cabinet ministers refused to attend any receptions where blacks or coloureds might be present", and that "the Afrikaner poet Breyten Breytenbach was denied permission to bring his Vietnamese wife into the country to meet his parents; that a black workman could hold two wires for a white electrician but was not allowed to join them together". ${ }^{5}$

Separating citizens according to skin color is a shameful economic policy, regardless of the promised happiness. The arrest of an innocent man must not be tolerated, even if the prisoner claims to be happy with the jail. Immoral practices, such as slavery, cannot be justified under the argument that the majority feels comfortable with such a disgrace. There are values other than happiness which refute certain decisions, irrespective of their effects on the feelings of the affected persons. ${ }^{6}$ In this regard, Steve Biko noted that apartheid constitutes a form of "sadism". While this term is generally used with reference to sexual conduct, Biko interpreted it in terms of the relationship between the state and its citizens. This interpretation is applicable because apartheid was not a form of individualist sadism, but an institutionalised set of sadistic practices imposed by the figure of the state, its organs, and authorities. Biko develops this argument through the example of the author, Barnett Potter, who took pleasure in blaming the black communities for the alien economic exploitation which they suffered. Biko explains that "we can listen to the Barnett Potters concluding with apparent glee and with a sense of sadistic triumph that the fault with the black man is to be found in his genes (...)". ${ }^{7}$ Potter's argument had been that black individuals deserve their unhappiness and their struggles because they do not contribute to the sum of human happiness.

This is an example of the misuse of a doctrine in order to deny citizens their rights. It is a way to engender blame and an inferiority complex. The South African government created the impression that the continent was being looted by external economic interests and that the fault belonged to the black community. This irrational impression is evidence of the state's behavior as a form of sadistic pleasure.

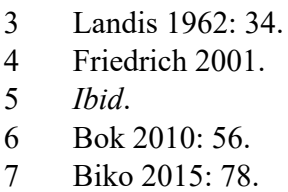


Potter referred to the black community as follows: "They stay alive thanks to grants-in-aid, loans and various forms of subvention, but they contribute little, if anything, to the sum of human happiness and welfare and less to the total of human knowledge and goodness. They are the burden of our time."

Biko exposes the effects of apartheid through explaining that "all in all the black man has become a shell, a shadow of man, completely defeated, drawing in his own misery, a slave, an ox bearing the yoke of oppression with sheepish timidity". ${ }^{9}$ Biko's explanation of apartheid represents it as a means to violate crucial human feelings, such as fulfilment, self-confidence, self-esteem, and self-respect. There was a total loss of dignity.

There is no right to sadistic pleasures when the people are affected, directly or indirectly, by institutionalised practices of discrimination. If happiness is correctly interpreted, it becomes a value that encompasses a strong commitment to the realisation of other values, such as democracy, freedom, objective well-being, subjective well-being, and human dignity. Happiness should not, and cannot, be used as justification for prejudice and cruelty, as the apartheid regime attempted to do.

\section{SUPREMACY AS SADISTIC PLEASURE}

Apartheid may be interpreted as being based on a form of sadism, a harmful sentiment much appreciated in nationalistic regimes which prevailed, for instance, during World War II. ${ }^{10}$ Its mechanisms of control and its ideology are based on the premise that it is possible to feel pleasure due to the infliction of pain on others. In this regard, persistent and intentional prejudice is a perverse form of pain. Sadistic pleasures may be derived from a sense of superiority, as well as from the enactment of revenge. Sadistic pleasure encompasses a sentiment of ecstasy felt by inflicting harm to others, and may be regarded as a moral aberration. It is not relevant whether this pleasure is felt by a white man or by a black man. In its application to the apartheid regime, it is a representation of the exacerbation of a moral failure.

Hannah Arendt recounts the horrors experienced in Nazi Germany by the Jewish people in the concentration camps during World War II. Arendt explains that torture was "an essential feature of the whole totalitarian police and judiciary apparatus; it ... was used every day to make people talk". ${ }^{11}$ Torture and prejudice may be interpreted in the same light, inasmuch as neither is excusable as a means to an end.

8 "White's book about Blacks controversial" 17 May 1971 Utica NY Daily Press available at http://www.fultonhistory.com/Process\%20small/Newspapers/Utica\%20NY\%20Daily\%20Press/ Utica\%20NY\%20Daily\%20Press\%201971.pdf/Utica\%20NY\%20Daily\%20Press\%201971\%20 -\%203501.pdf(accessed 1 Mar 2016).

9 Biko 2015: 31.

10 Arendt 1951: $448 \mathrm{n} 144$ recommends the perusal of the testimony of Mrs Buber-Neumann (former wife of the German Communist Heinz Neumann), who survived Soviet and German concentration camps: "The Russians never ... evinced the sadistic streak of the Nazis ... Our Russian guards were decent men and not sadists, but they faithfully fulfilled the requirements of the inhuman system." 
Arendt also highlights the connection between Nazi concentration camps and sadistic pleasures: "To this rationally conducted torture another, irrational, sadistic type was added in the first Nazi concentration camps and in the cellars of the Gestapo." 12 She explains that the theoretical basis of the Nazi Party is based on the works of the Marquis de Sade, from whom the term "sadism" stems. Arendt states that "to them, violence, power, cruelty, were the supreme capacities of men who had definitely lost their place in the universe and were much too proud to long for a power theory that would safely bring them back and reintegrate them into the world". ${ }^{13}$

Every project of absolute power carries the possibility of being based on actions which tolerate the suffering of others. Megalomania brings about the capacity of being insensitive to another's pain, provided that the ultimate goals are achieved. Apartheid may be interpreted to be a megalomaniac project because its supporters believed that only a part of society deserved happiness, and that members of society could be used in order to further the happiness of others, an example of which is slavery. Apartheid thus ignored and disrespected the human dignity principle, which led to the corruption of the idea of happiness.

The use of happiness to deny basic human rights may be explained in terms of the Plessy $v$ Ferguson case, which was heard by the US Supreme Court. ${ }^{14}$ In this instance, James Walker stated that "the real evil lies not in the colour of the skin but in the relation the coloured person sustains to the white. If he is a dependent, it may be endured: if he is not, his presence is insufferable". Furthermore, "instead of being intended to promote the general comfort and moral well-being, this act is plainly and evidently intended to promote the happiness of one class by asserting its supremacy and the inferiority of another class". ${ }^{15}$ This is not happiness; it is the infliction of misery fabricated by a sense of superiority that intentionally inflicts pain on others.

Walker's argument coincides with Biko's, inasmuch as "while we progressively lose ourselves in a world of colourlessness and amorphous common humanity", the heads of apartheid and those who enjoy the advantages of an unfair system "are deriving pleasure and security". ${ }^{16}$

Far from revealing any facet of happiness, regimes based on racism, such as apartheid, are a pure form of ideology sustained by the commitment to exacerbation of sadistic pleasure, precisely because their sense of superiority mirrors a perception

11 Idem at 144: Arendt recommends the perusal of the testimony of Mrs Buber-Neumann (former wife of the German Communist Heinz Neumann), who survived Soviet and German concentration camps: "The Russians never ... evinced the sadistic streak of the Nazis ... Our Russian guards were decent men and not sadists, but they faithfully fulfilled the requirements of the inhuman system."

12 Idem at 453.

13 Idem at 330-331.

14 Plessy v Ferguson 163 US 537 (1896) at 539.

15 Junior, Higginbotha \& Ngcobo 1990: 809 n 198.

16 Biko 2015: 55. 
of the other as being inferior, and therefore less deserving of consideration and respect. It presents itself as a school of thought which becomes threatened when the others' projects of happiness are successfully implemented; and, as previously stated, this constitutes a form of sadism inasmuch as it aims to diminish the other socially, morally, and intellectually.

\section{PERVERSE PLEASURES}

The word "sadism" dates back to 1834. Psychiatrist Krafft-Ebing used the term medically, in terms of psychopathology in 1891, explaining that sadism is a component of "lust-murder and violation of corpses ... in which injury of the victim of lust and sight of the victim's blood are a delight and pleasure". He also noted that "the notorious Marquis de Sade, after whom this combination of lust and cruelty has been named, was such a monster". ${ }^{17}$ Sadism comprises any pleasure experienced through the infliction of suffering. The sadistic pleasures derive from the humiliation of another party, their domination, subjugation, or even infliction of pain.

David Bilchitz explains the controversy of the concept of "triumphant pain". He points out that "pain involves a particular type of phenomenological experience, one that can be regarded as having a particular descriptive content". For him, "it is also a state which all beings with subjective conscious experience find unpleasant". He adds that "to experience pain is to have an experience of something that is of disvalue to a being". ${ }^{18}$ Bilchitz explains that the universal trait of pain is that "each individual can be asked to evaluate whether this claim is true", and, by the same token, "the linguistic and non-linguistic behaviour of beings that accompany painful experiences can provide evidence as to how they regard those experiences". ${ }^{19}$

Sadistic pleasures could thus never be integrated into the formula of the right to happiness. This contribution is crucial in terms of this paper's illustration of the integration of prohibiting sadistic pleasures under the umbrella of human dignity.

The British colonial writer, Richard Burton, wrote that slaves taken from their ancestral lands in Africa lived a life of paradise and in a land of happiness on whiteowned slave plantations in the United States and in the colonial West Indies. ${ }^{20}$ Is this perverse pleasure a genuine form of happiness? Should society support a collective project of happiness based on the suffering and deprivation of the others?

Stuart Mill uses Aristotle's argument to differentiate the qualities of pleasures, in terms of intensity and quality. While he does not indicate whether a pleasure is noble or perverse, the differences between the qualities of pleasure create a matrix against which one may examine the principle of human dignity as a limitative factor, a line

Von Kraft-Ebing 1939: 105.

18 Bilchitz 2015: 24.

19 Idem at 25.

20 Kaplan 1996: passim. 
whereby we can prevent the excess of the utilitarianism or an abusive utilisation of the discourse of the right to happiness,${ }^{21}$ which happened in South Africa during apartheid.

Mill stresses that men have greater pleasure in subordinating women, because this makes them feel superior. However, when assessing the gains for the society that sexual equality would provide, Mill does not consider the possible pain that men could experience due to the revocation of their privileges. Such pleasure would not be beneficial for social well-being.

Bilchitz expands upon this approach, distinguishing the qualities of pleasure and pain. He explains that "pain involves not only having a particular phenomenological experience, but that such an experience also involves a particular qualitative state that has either positive or negative value for that being". ${ }^{22}$ Bilchitz continues to argue that the intrinsic trait of being a bad experience, regardless of the sadist's opinion thereof, is that "there are in fact certain experiences - such as pain and starvation - that are negative for all beings that experience them. It does not require us to believe that pain in certain instances is "good"'. ${ }^{23} \mathrm{He}$ continues to state that "for most individuals, living in a continual state of pain would be a miserable existence, having little value". ${ }^{24}$

This paper demonstrates that pleasures can be identified as noble and perverse. There are sadistic pleasures which corrupt fundamental moral agreements and rights, and the apartheid regime was supported by individuals who were inclined to indulge in perverse pleasures.

\section{ECONOMIC TRAUMA TRANSLATED INTO CONSTITUTIONAL PROVISIONS}

The study of happiness comprises the examination of the implementation of public policies which focus on objective and subjective well-being. In this regard, Biko argues that "there is no doubt that the colour question in South African politics was originally introduced for economic reasons". ${ }^{25}$ From this perspective, apartheid, despite being a system that worked as a powerful instrument of enrichment for some, is not considered to be a good model, precisely because it embraced sadistic pleasures. The result of such a model is evidenced by the South African economy, despite alleged economic development, which was not separated from concerns relative to subjective well-being.

25 Biko 2015: 96. 
Due to this intense economic side effect, Constitutions of African countries highlighted a multitude of concerns about external economic exploitation and have inserted provisions driving economic development towards a deeper purpose comprising freedom, prosperity, and people's happiness in response to the collective trauma.

To illustrate, article 1 of the Constitution of Liberia, 1986, proclaims that all free governments are instituted by the people's authority, and for their benefit, and they have the right to alter and reform the same when their safety and "happiness" so require. ${ }^{26}$ In Egypt, the 2014 Constitution provides "a place of common happiness for its people". The Namibian Constitution, 1990, assures the right "to the pursuit of happiness"; this provision means a reaction against racism.

The right to the pursuit of happiness means the right to be a free man, someone whose fate is not in the hands of those who believe in a world where rights depend on skin colour. It is the right to live a life free of oppression, free from the yoke imposed by the strangulation of projects of happiness.

In this regard, Frederick Fourie argues that the preamble of the Namibian Constitution is coloured by the struggle against colonialism and racism. He explains that "this is built around the denial of the "right of the individual life, liberty, and the pursuit of happiness' by colonialism, racism, and apartheid". ${ }^{27}$ In other words, colonialism, racism, and the apartheid economic policy caused human structures to collapse by denying singular aspects of any project of happiness, such as popular participation and freedom.

Namibia is not alone in its efforts to assure the right to happiness for its citizens. Article 36(1) of the Constitution of Ghana, 1992, assures that the State shall take all necessary action to ensure that the national economy is managed in such a manner as to maximise the rate of economic development and to secure the maximum welfare, freedom, and "happiness" of every citizen. ${ }^{28}$ Similarly, article 16(1)(b) of the Nigerian Constitution, 1999, assures that the State shall control the national economy in such manner as to secure the maximum welfare, freedom, and "happiness" of every citizen on the basis of social justice and equality of status and opportunity. ${ }^{29}$ This provision is also present in the Nigerian Constitution of $1979 .{ }^{30}$

26 See ch 1 (Structure of the State) of the Constitution.

27 Fourie 1990: 363.

28 See ch VI of the Constitution (The Directive Principles of State Policy) which provides economic objectives.

29 See ch II of the Constitution (Fundamental Objectives and Directive) which establishes the principles of State policy.

30 Read 1979: 171. The author explains that article 16(i) of the 1979 Nigerian Constitution states that "[t]he State shall, within the context of the ideals and objectives for which provisions are made in this Constitution (a) control the national economy in such manner as to secure the maximum welfare, freedom, and happiness of every citizen on the basis of social justice and equality of status and opportunity". 
The preamble of the Constitution of Swaziland, 2005, envisages guaranteeing peace, order, good government, and the "happiness" and welfare of all Swazi people. It then presents practically the same provision of the Constitutions of Ghana and Nigeria. Article 59(1) states that "the State shall take all necessary action to ensure that the national economy is managed in such a manner as to maximize the rate of economic development and to secure the maximum welfare, freedom, and happiness of every person in Swaziland and to provide adequate means of livelihood and suitable employment and public assistance to the needy". ${ }^{31}$

The South African Freedom Charter, which resembles a Declaration of Independence, provides the same concern about the strength of money in relation to national goods. Instead of using the word "happiness", as other African Constitutions do, the document contains the phrase "well-being" for the sake of legislation. It provides that "all other industry and trade shall be controlled to assist the well-being of the people".

It seems to be evident that the colonisation of African countries left a heritage of an ingrained sense of repulsion against any form of economic exploitation, or what Biko calls "capitalistic exploitative tendencies" ${ }^{32}$ Constitutions of relevant countries, including that of an economic giant like Nigeria, and the South African Freedom Charter, have inserted constitutional provisions which expel the overwhelming power of money and, simultaneously, associate economic development with welfare, happiness, and freedom. These Constitutional provisions represent the reaction to the collective trauma that these countries experienced due to latent economic exploitation maintained throughout African history. It is a way to say "never again".

\section{THE CONSTITUTIONAL BARRIER AGAINST SADISTIC PLEASURES}

The Constitution of South Africa built a barrier trying to minimise the inevitable presence of pain in people's life, as well as to avoid the exhortation of sadistic

31 See Maseko 2008: 317-318. Maseko shares a critical point of view in terms of the constitutionmaking process in Swaziland, asking, "Who are the people? Who is the nation?" He then explains that "this is precipitated by the fact that, more often than not, African leaders refer to and purport to do things for and on behalf of their 'people' or the 'nation', even if the decisions they take are detrimental to the very people they lead. This is significant in the context of Swaziland because, when the 1968 Independence Constitution was repealed, the King supposedly acted for and with the full consent of the Swazi people: [T] hat I and my people heartily desire at long last, after a long constitutional struggle, to achieve full freedom and independence under a Constitution created by ourselves for ourselves in complete liberty without outside pressures; as a nation we desire to march forward progressively under our own Constitution guaranteeing peace, order and good government and the happiness and welfare of all our people". See also ch V (Directive Principles of State Policy and Duties of the Citizen) of the Constitution, disciplining the economic objectives.

32 Biko 2015: 107. 
pleasures as being a natural part of happiness. The National Anthem urges that South Africans "stop wars and tribulations", showing the collective trauma historically faced by the country. This recognition is emphasised by the preamble to the Constitution which states that "we, the people of South Africa, recognize the injustices of our past; honour those who suffered for justice and freedom in our land (...)".

The Constitution houses concern about suffering, and challenges different forms of sadistic pleasures. Section 1 founds the values of the Republic of South Africa, including "non-racialism and non-sexism". Section 6(2) recognises the historically diminished use and status of the indigenous languages of the South African people. Section 9 disciplines commitments in terms of "equality", highlighting unfair discrimination in the areas of race, gender, sex, pregnancy, marital status, ethnic or social origin, colour, sexual orientation, age, disability, religion, conscience, belief, culture, language, and birth.

Section 12(1) shows its commitment to the avoidance of any form of sadistic pleasure. According to this section, "everyone has the right to freedom and security of the person, which includes the right (c) to be free from all forms of violence from either public, or private sources; (d) not to be tortured in any way; and (e) not to be treated or punished in a cruel, inhuman, or degrading way". These provisions establish an unalterable commitment to the avoidance of any form of sadistic pleasure. This provision is complemented by section 13, which establishes that "no one may be subjected to slavery, servitude, or forced labour".

The Constitution did not neglect its necessary attention to an environment that is not harmful to society. Section 24(1)(a) assures that everyone has the right to an environment that is not harmful to their health or well-being.

The Constitution of South Africa contains various provisions which protect its citizens from a painful existence. With regard to children, for instance, section 28(1) (d) states that every child has the right to be protected from maltreatment, neglect, abuse, or degradation. Even the oath of the President and acting President brings a duty of protecting people against any form of pain: "I solemnly and sincerely promise that I will always promote all that will advance the Republic, and oppose all that may harm it."

Finally, section 198(a) states that national security must reflect the resolve of South Africans, as individuals and as a nation, "to be free from fear and want and to seek a better life."

These constitutional provisions are designed to prevent any form of "apartheid flash-back", which would mean the return to a time where happiness was promised and pain was delivered.

\section{HUMAN DIGNITY AS A LIMITATIVE FACTOR}

The human dignity principle is able to establish a boundary against any excess derived from the misuse of the right to happiness. It is a belief in the human being's 
capability of being content. Biko affirms that "I've got no doubt in my mind that people - and I know people in terms of my own background, where I stay - are not necessarily revengeful, nor are they sadistic in outlook". ${ }^{33}$

While there are various definitions of human dignity, for the purpose of this paper, the most fitting definition of human dignity comes from Steve Biko's "African Cultural Concepts". Biko explains human dignity as follows:

We believe in the inherent goodness of man. We enjoy man for himself. We regard our living together not as an unfortunate mishap warranting endless competition among us but as a deliberate act of God to make us a community of brothers and sisters jointly involved in the quest for a composite answer to the varied problems of life. Hence in all we do we always place Man first and hence all our action is usually joint community oriented action rather than the individualism which is the hallmark of the capitalism approach. We always refrain from using people as stepping stones. Instead we are prepared to have a much slower progress in an effort to make sure that all of us are marching to the same tune. ${ }^{34}$

Biko attributes an intrinsic value to human beings, thus seeing the human being as an end, not as a means to an end. For Biko, the human being has self-value, an indispensable and inalienable right. This equates to human dignity. Biko's concept has been embodied by the South African Constitution.

Section 1(a) establishes the fundamental values of the Republic of South Africa, including "human dignity". Section 7(1) reaffirms the democratic value of human dignity. Section 10 proclaims that everyone has inherent dignity, and the right to have their dignity respected and protected. Section 35(2)(e) states that everyone who is detained has the right to conditions of detention that are consistent with human dignity. Section 39(1)(a) assures that when interpreting the Bill of Rights, a court, tribunal, or forum must promote the values that underlie an open and democratic society based on human dignity, equality, and freedom.

The protection of human dignity is the most precise mechanism to prevent the appeal for happiness to become an exhortation of sadistic pleasures. Therefore it is essential to recognise that human dignity is the foundation of the major part of the Constitutional texts.

Human dignity is the constitutional vector that prevents the right to happiness from converting itself into grounds for cruel practices, based on sadistic pleasures, which, instead of enhancing civilizing expeditions, destabilises constitutional conquests.

Human dignity also has a crucial limitative effect on the excess of the principle of utility. Consequently, it is a boundary to the misuse of the right to happiness. It is not possible to justify a harmful action based on the convenient argument that the action causes the actor happiness. There is no right to happiness in hurting others.

33 Idem at 170.

34 Idem at 46. 
This is a sadistic pleasure which must be curbed by the human dignity principle. As the right to happiness counts everyone equally, the damage caused even to one person has undeniable value and weight.

\section{CONCLUSION}

Hendrik Verwoerd was wrong. Happiness cannot flourish in a land without popular participation; in soil where freedom was just a remote idea; in a place where inconceivable inequality prevailed; where there was no regard for subjective wellbeing; where an institutionalised brutality eroded any sense of human dignity. Verwoerd's argument was echoed by Judge Ruffin, of the Supreme Court of the United States, in the case of State $v$ Mann, for whom "the slave did not deserve any happiness or personal comforts, while white people did". ${ }^{35}$

It is a question of principle. Steve Biko correctly stated that "apartheid - both petty and grand - is obviously evil". ${ }^{36}$ There is no happiness under the oppression of one over another, regardless of skin colour. The prohibition of sadistic pleasures is a fundamental dimension of the right to happiness.

This dimension of the right to happiness may be interpreted to be the foundation of the causes and values enshrined in the South African Constitution, which is designed to remind future generations of South Africans of the pitfalls of the sense of superiority, prejudice, and disregard for others' pain as a means of dominance.

\section{ABSTRACT}

South African history is intrinsically linked to the apartheid era and its inevitable and persistent consequences. These consequences show that in some extreme political situations, leaders try to impose their ideology, and, in doing so, use either Constitutional rights or moral values as rhetorical scapegoats in order to dismantle our deepest commitment to ourselves in terms of our pursuit of happiness. In light of the historical documents that preceded the inauguration of the apartheid era, it is possible to identify that happiness appeared as a pivotal value under which the apartheid order would be erected. This paper aims to investigate the relation between apartheid and the misuse of happiness as a core value, addressing the idea of sadistic pleasure as a deformation of the ideal of human rights. Finally, the paper shows how the Constitution of South Africa, as well as other African Constitutions, has instituted the right to happiness in order to overcome the collective trauma generated by racism.

36 Biko 2015: 26. 


\section{CONSTITUTIONAL SCAPEGOAT}

\section{BIBLIOGRAPHY}

Arendt, H (1951) The Origins of Totalitarianism (New York, NY)

Bilchitz, D (2015) Poverty and Fundamental Rights. The Justification and Enforcement of SocioEconomic Rights (New York, NY)

Biko, S (2015) I Write What I Like: A Selection of His Writings (Johannesburg)

Bok, D (2010) The Politics of Happiness: What Government can Learn from the New Research on Wellbeing (New Jersey, NJ)

Fourie, F (1990) "The Namibian Constitution and economic rights" South African J on Human Rights 6: 363-365

Friedrich, O (2001) "United no more" available at http://content.time.com/time/magazine/ article/0,9171,146510,00.html (accessed 1 Mar 2016)

Junior, LH, Higginbotha, FM \& Ngcobo, S (1990) "De jure housing segregation in the United States and South Africa: The difficult pursuit for racial justice" University of Illinois LR (Fall 1990): 764-878

Kaplan, RD (1996) The Ends of the Earth: A Journey at the Dawn of the 21st Century (New York, NY)

Landis, ES (1962) "South African apartheid legislation: Fundamental structure" Yale LJ 71: 1-52

Maseko, T (2008) "The drafting of the Constitution of Swaziland, 2005" African Human Rights LJ 8: $312-336$

Read, JS (1979) “The new Constitution of Nigeria, 1979: 'The Washington Model?"” J of African Law 23 (2): 131-174

Varennes, F (2008) "Constitutionalising discrimination in Bhutan: The emasculation of human rights in the Land of the Dragon" Asia-Pacific J on Human Rights and the Law 2: 47-76

Verwoerd, HF (1961) The Truth about South Africa (Address by the Honourable Prime Minister of the Union of South Africa, Dr Verwoerd before the South Africa Club in the Savoy Hotel) (London, 17 March 1961), Bloemfontein: National Party's Information Service [1961] (OCoLC) 648220436

Von Kraft-Ebing, R (1939) Psychopathia Sexualis: A Medico-Forensic Study (London)

\section{Case law}

Plessy v Ferguson 163 US 537 (1896)

State v Mann 463 NW 2d 883 (1990) OR 244 NJ Super 622 (1990) OR 582 A 2d 1048 (NJ Super, 1990) at https://www.courtlistener.com/opinion/2210759/state-v-mann/ 